\title{
Prevalence, intensity and abundance of endoparasites in Oreochromis niloticus and Tilapia zilli (Pisces: Cichlidae) from Asa Dam, Ilorin, Nigeria
}

\author{
C. Ebube Amaechi \\ Department of Zoology, Faculty of Life Sciences, University of Ilorin, P.M.B.1515, Ilorin, Nigeria; ebubeamechi@yahoo.com
}

Received 03-VI-2014 • Corrected 12-IX-2014 • Accepted 20-X-2014

\begin{abstract}
Disease is an important factor in fisheries, affecting both wild and cultured species. Using standard parasitological techniques we determined the prevalence, mean intensity and abundance of endoparasites from 250 specimens of two cichlids, Oreochromis niloticus and Tilapia zilli from Asa dam, llorin, North Central Nigeria between February and August, 2013. We found two digenetic trematode parasites: Euclinostomium heterostomum and Clinostomum tilapiae. The highest prevalence was recorded in O. niloticus $(35,9 \%)$ infested by $C$. tilapiae, while the highest mean intensity was recorded in T. zilli. There was no relationship ( $p>0,05)$ between parasite burden and fish size (length and weight). Male fish were more heavily infected than females. The overall health status of both fish species remained unaffected. The high rate of pollution noticed in the study area might be favoring parasite load. Therefore, pollution control and regular surveillance of the water body are advocated.
\end{abstract}

Key words: parasites; flatworms; cichlids; Asa Dam; Nigeria.
RESUMEN: Las enfermedades son un factor importante en la pesca, afectando especies silvestres y cultivadas. Mediante el uso de técnicas parasitológicas estándar se determinó la prevalencia, intensidad y abundancia de endoparásitos en 250 especímenes de dos cíclidos, Oreochromis niloticus y Tilapia zilli de la represa Asa, Ilorin, Nigeria del Norte Central, entre febrero y agosto del 2013. Encontramos dos parásitos trematodos digenéticos; Heterostomum Euclinostomium y Clinostomum tilapiae. La prevalencia más alta se registró en O. niloticus $(35,9 \%)$ que fue infestado por C. tilapiae, mientras que la media más alta de intensidad se registró en T. zilli. No hubo relación $(p>0,05)$ entre la carga parasitaria y tamaño de los peces (longitud y peso). Los machos fueron más infectados que las hembras. El estado de salud de las dos especies de peces no se vio afectado. La alta tasa de contaminación en el área de estudio podría ser responsable de la aparición del parásito registrado. Por lo tanto, se recomienda el control de la contaminación y la vigilancia regular de la masa de agua.

Palabras clave: parásitos; platelmintos, cíclidos; represa Asa; Nigeria.
Disease is an important factor in fish production, and this commercially important source of animal protein is susceptible to infections with various parasites (Emere, 2000). Helminthes are among the most important parasites and include nematodes, trematodes, cestodes and acanthocephalans affecting both wild and cultured fishes (Hussen, Tefera \& Asrate, 2012). These diseases are closely linked to environmental deterioration and stress. The importance of parasitic infection on fish production has remained an issue of concern to fish farming industry. Fishes especially the cichlids are widely distributed in African water bodies due to their high productivity rate and their ability to adapt to various climatic conditions (Onwuliri \& Mgbemena, 1987). Parasites usually compete for food thereby depriving fish of its essential nutrients as such distorting growth which invariably leads to morbidity and mortality with consequent economic losses.
Earlier investigations on the parasites of freshwater fishes in Nigeria include those of Onwuliri and Mgbemena (1987), Ugwuzor (1987), Ezenwaji and Ilozumba (1992), Bichi and Ibrahim (2009), Awharitoma and Ehigiator (2012), Ohaeri (2012), Keremah and Inko-Teriah (2013).

The increased demand on fish has made the need for a continuous study on fish fauna and parasites of paramount importance. Therefore, this study aimed at investigating the prevalence and intensity of parasitic infections in Asa dam a commercially fishing centre in Ilorin, North Central Nigeria.

\section{MATERIALS AND METHODS}

Study area: Asa Dam a major river in llorin the capital of Kwara State is located approximately $4 \mathrm{Km}$ South 
of Ilorin Townships. It is located between latitudes $80^{\circ} 28^{\prime \prime}$ and $80^{\circ} 52^{\prime \prime} \mathrm{N}$ and longitudes $40^{\circ} 35^{\prime \prime} \mathrm{E}$ and $40^{\circ} 45^{\prime \prime} \mathrm{E}$. Asa reservoir has a surface area of 302 ha with a maximum length of $18 \mathrm{Km}$ and a maximum depth of about $14 \mathrm{~m}$ at the dam site. The climatic condition of the study area is characterized by two distinct seasons, the wet and dry seasons respectively. The area has an annual rainfall of $1133,9 \mathrm{~mm}$ and the vegetation is typical of Northern guinea savanna. It has a population estimate of 2371089 (NPC, 2006). The inhabitants of the area speak languages such as Yoruba, Hausa, Fulani, Nupe, and Baruba. They are basically fishermen and farmers in the study area.

Collection, Identification and Processing of Fish samples for parasite examination: The fishes were caught by the fishermen using gill nets (mesh size, $3 \mathrm{~cm}$ ) which was set in the evening and retrieved the following morning. The fishes were placed in an ice-chest and transported to the Parasitology laboratory in the Department of Zoology, University of Ilorin for identification, processing and examination for parasitic helminthes. The fish samples were identified to the species level using taxonomic keys (Yamaguti, 1963). The total length and standard length measurements were taken using a calibrated dissecting board. The weight of each fish was taken using a sensitive weighing balance (metler $0.01 \mathrm{~g}$ ). Reference number was assigned to each fish to allow for proper documentation of records obtained. Sexes of the fish were obtained after dissection. The skin, scales, eyes and gut of the fishes were all removed with the aid of a dissecting tool. These organs were immediately immersed in a saline water to aid the emergence of parasites.

Killing and preservation of parasites: The parasites that were gotten were cleared by washing them in saline water for 30min after which they were killed and fixed in Alcohol- Formalin-Acetic Acid (AFA) solution for 24hours. This was later transferred to a $70 \%$ alcohol solution.

The staining method was used for the treatment of Acanthocephala where the parasites were dehydrated using alcohol at different concentrations: $70 \%$ alcohol,
$85 \%$ alcohol, $95 \%$ alcohol and $100 \%$ alcohol for a period of $10 \mathrm{~min}$ each. After dehydration, the parasites were cleared in xylene and stained with acetic hematoxylin for $15 \mathrm{~min}$. The parasites were then mounted on a slide warmer for $10 \mathrm{~min}$ for the curing process to take place.

After dehydration, the parasites were cleared in xylene and mounted on a slide using DPX. The slides were later placed on a slide warmer for $10 \mathrm{~min}$. Later on the slides were observed under a light microscope and the parasites identified using information provided by Yamaguti (1963).

Statistical analysis: The relationship that exists between the parasite burden and other tested variables (length, weight and sex) were compared using correlation analysis and t-test. P-values equal to or less than 0,05 were considered significant (Steel \& Torrie, 1980).

\section{RESULTS}

Out of the 250 specimens examined, $141(56,4 \%)$ were found to be infected with parasitic diseases. Two helminthic trematodes were obtained: Euclinostomium heterostomum and Clinostomum tilapiae.

Table 1 shows the prevalence and intensity of parasites as recovered in the hosts. The highest prevalence $(35,9)$ was obtained in O. niloticus that was found to be infested with Clinostomum tilapiae, while the highest mean intensity $(3,18)$ was recorded in $T$. zilli infested also with Clinostomum tilapiae.

The relationship between parasite burden and sex as seen in Table 2 showed no significant difference ( $p$ $>0,05$ ). Table 3 shows the relationship between parasite burden and length of fish. There was no relationship between parasite burden and length $(p>0,05)$. Table 4 shows the relationship between parasite burden and weight. There was no relationship between parasite burden and body weight.

TABLE 1

Helminths of $O$. niloticus and T. zilli from Asa dam, north central Nigeria

\begin{tabular}{|c|c|c|c|c|}
\hline Host & Helminth & Number infected & Prevalence (\%) & Intensity \\
\hline \multirow[t]{2}{*}{ O. niloticus } & E. heterostomum & 35 & 24.1 & $1.33 \pm 0.56$ \\
\hline & C. tilapiae & 52 & 35.9 & $2.01 \pm 1.35$ \\
\hline \multirow[t]{2}{*}{ T. zilli } & E. heterostomum & 25 & 23.8 & $1.98 \pm 0.87$ \\
\hline & C.tilapiae & 29 & 27.6 & $3.18 \pm 1.61$ \\
\hline
\end{tabular}

* No of O. niloticus examined=145; no of T.zilli examined=105; Total specimen examined=250. 
TABLE 2

Relationship between sex and parasite burden in fish

$\begin{array}{lcccccc}\text { Host } & \text { Sex } & \text { No infected } & \text { Mean parasite load } & \text { Df } & \text { t } & \text { Significance } p=0.05 \\ \text { O. niloticus } & \text { M } & 56 & 3,85 & 11 & 1,89 & \text { NS } \\ \text { T. zilli } & \text { F } & 31 & 2,71 & & & \\ & \text { M } & 55 & 3,78 & & \\ \end{array}$

TABLE 3

Relationship between parasite burden and length of fish

\begin{tabular}{lcc}
\multicolumn{1}{c}{ Species } & $\mathrm{R}$ & Significance \\
O. niloticus & 0,0841 & $\mathrm{n} . \mathrm{s}$ \\
T. zilli & 0,2472 & $\mathrm{n} . \mathrm{s}$ \\
\hline
\end{tabular}

TABLE 4

Relationship between parasite burden and body weight of fish

\begin{tabular}{lcc}
\multicolumn{1}{r}{ Species } & $\mathrm{R}$ & Significance $(\mathrm{p}=0.05)$ \\
O. niloticus & 0,006 & n.s \\
T. zilli & 0,197 & n.s \\
\hline
\end{tabular}

\section{DISCUSSION}

The study showed a high infection rate $(56,4 \%)$ in all the fishes examined. This is similar to the findings of Morenikeji and Adepeju (2009) in Eleyele dam in Ibadan, South western Nigeria and Onyedineke, Obi, Ofoegbu and Ukogo (2010) in river Niger at llushi in Edo State that reported similar results. Two species of helminthes, E. heterostomum and C. tilapiae were the only parasites recovered in this study. These parasites have also been recovered from cichlids and other fresh water species (Ukoli, 1970; Olurin \& Somorin, 2006; Morenikeji \& Adepeju, 2009; Ohaeri, 2012). Paperna (1980) noted that the occurrence of $E$. heterostomum and C. tilapiae were widespread amongst cichlids. Factors that could have contributed to the diversity and survival of parasite fauna of fish in the study area include host age, diet, habitat, and migratory behavior (Stock \& Holmes, 1986). The two trematodes recovered were found mostly in the intestines which are associated with the digestion activity that normally results in the release of parasite ova/ cysts in food particles.

Previous findings have shown that helminthes are mostly found in fresh water fishes where factors such as parasite species and its biology, host and its feeding habitats, physical factors, hygiene of the water body and presence of intermediate hosts contribute to their prevalence and intensity (Chandra, 2006; Hussen et al., 2012). In this study, more males were infected than females $(p \leq 0,05)$. This is consistent with the findings of earlier researchers (Aloo, 2002; Biu \& Nkechi, 2013; Ohaeri, 2012; Olurin et al., 2012). However detailed explanations in literature as regards the relationship between sex and prevalence are scarce. Emere (2000) attested differences in infestation between males and females to differential feeding pattern which could be in terms of quality and quantity. It could also be attributed to differences in the degree of resistance to infection. The physiological state of the female fishes could have reduced resistance to infection by parasites (Emere \& Egbe, 2006). There was no relationship between parasite burden and size of fish. Previous reports are however inconsistent with this findings (Olurin \& Somorin, 2006). There has been contrasting results obtained between parasite burden and size of fish (length and weight). Other previous studies reported relationship between length and weight (Price \& Clancy, 1983), while in others there was no relationship (Sasal, Morand \& Guegan, 1997).

In the present study environment, farmers dispose off their waste and faecal matters close to the dam which is subsequently washed into the dam thus providing suitable conditions for parasites to thrive.

The problem of fish infestation by parasites in the dam could be best handled through proper management procedures that will help eliminate the suitable conditions favouring the parasite infestation. Regular surveillance of the water body for parasites and pollution control will go a long way in controlling parasitic infestation in the dam.

\section{ACKNOWLEDGEMENTS}

We are grateful to the Department of Zoology University of Ilorin, Ilorin Nigeria, especially the technical staff in the Laboratory for all their support and assistance rendered in the course of doing this work. 


\section{REFERENCES}

Aloo, P. A. (2002). A comparative study of helminth parasites from the fish Tilapia zilli and Oreochromis leucostictus in Lake Nairasha and Oloiden Bay, Kenya. Journal of Helminthology, 76(2), 95-104.

Awharitoma, A. O., \& Ehigiator, F. A. R. (2012). Helminth parasites of fishes from some rivers in southern Nigeria. African Scientist, 13(2), 65-69.

Bichi, A. H., \& Ibrahim, A. A. (2009). A survey of ecto and intestinal parasites of Tilapia zilli(Caervias) in Tiga Lake, Kano, Northern Nigeria. Bayero Journal of Pure and Applied Science, 2(1), 79-82.

Biu, A. A., \& Nkechi, O. P. (2013). Prevalence of Gastrointestinal Helminths of Tilapia zilli(Gervais 1848) in Maiduguri, Nigeria. Nigerian Journal of Fisheries and Aquaculture, 1(1), 20-24.

Chandra, K. J. (2006). Fish parasitological studies in Bangladesh: A review. Journal of Agriculture and Rural Development, 4(1-2), 9-18.

Emere, M. C., \& Egbe, N. E. L. (2006). Protozoan parasites of Synodontis clarias (A freshwater fish) in river Kaduna. BEST Journal, 3(3), 58-64.

Emere, M. C. (2000). Parasitic infection of the Nile perch lates niloticus in River Kaduna. Journal of Aquatic Science, 15, 51-54.

Ezenwaji, H. M. G., \& Ilozumba, P. C. O. (1992). Helminth fauna of four West African small Clarias Species (Osteichthys: Claridae) from Nigeria. Journal of African Zoology, 106, 391-400.

Hussen, A., Tefera, M., \& Asrate, S. (2012). Gastrointestinal helminth parasites of Clarias gariepinus (Catfish) in Lake Hawassa Ethiopia. Scientific Journal of Animal Science, 1(4), 131-136.

Keremah, R. I., \& Inko-Tariah, M. B. (2013). Comparative study of ectoparasites on Nile Tilapia (Oreochromis niloticus) cultured under integrated and unintegrated pond systems. African Journal of Biotechnology, 12(19), 2711-2714.

Morenikeji, O. A., \& Adepeju, A. I. (2009). Helminth communities in Cichlids in natural and man-made ponds in South west Nigeria. Researcher, 1(3), 84-92.

NPC. (2006). 2006 National Census Provisional Results. National Population Commission, Abuja, Nigeria.
Ohaeri, C. C. (2012). Gut helminthes parasites and host influence in Nile Tilapia, Oreochromis niloticus. Journal of Biological Science and Bioconservation, 4, 38-43.

Olurin, K. B., \& Somorin, C. A. (2006). Intestinal helminthes of the fishes of Owa stream, south west Nigeria. Research Journal of Fisheries and Hydrobiology, 1(1), 6-9.

Olurin, K. B., Okafor, J., Alade, A., Asiru, R., Ademiluwa, J., Owonifari, K., \& Oronaye, O. (2012). Helminth parasites of Sarotherongalilaeus and Tilapia zilli (Pisces: Cichlidae) from River Oshun, South west Nigeria. International Journal of Aquatic Science, 3(2), 49-55.

Onwuliri, C. O. E., \& Mgbemena, M. O. (1987). The parasitic fauna of some fresh water fish from Jos Plateau, Nigeria. African Journal of Applied Fisheries and Hydrobiology, 2, 33-37.

Onyedineke, N. S., Obi, U., Ofoegbu, P. U., \& Ukogo, I. (2010). Helminth parasites of some freshwater fish from River Niger at Ilushi, Edo State, Nigeria. Journal of American Science, 6(3), 16-21.

Paperna, I. (1980). Parasites, infections and diseases of fish in Africa. CIFA Technical Paper, 7, 216.

Price, P. W., \& Clancy, K. M. (1983). Patterns in number of helminth parasite species fresh water fishes. Journal of Parasitology, 69, 449-454.

Sasal, P., Morand, S., \& Guegan, J. F. (1997). Determinants of parasite species richness in Mediterranean marine fish. Marine Ecolgy Progress series, 149, 61-71.

Steel, R. G. D., \& Torrie, J. H. (1980). Principles and Procedures of Statistics. $2^{\text {nd }}$ ed. New York: Mac GrawHill.

Stock, T. M., \& Holmes, J. C. (1986). Host specificity and exchange of intestinal helminthes among four species of grebes, podicipedidae. Canadian Journal of Zoology, 65, 669-676.

Ugwuzor, G. N. (1987). A survey of the helminthic parasites of fish in Imo river. Nigerian.Journal of Applied Fisheries and Hydrobiology, 2, 25-30.

Ukoli, F. M. A. (1970). On the adhesive mechanism of Apharyngostriages simplex and Clinostomum tilapiae. Nigerian Journal of Science, 4, 77-79.

Yamaguti, S. (1963). Systema Helminthum, the Acanthocephans. New York: Interscience Publishers. 